This is a pre-copyedited, author-produced version of an article accepted for publication in Journal of Economic Geography following peer review. The version of record Steve Burt, Ulf Johansson, John Dawson; Dissecting embeddedness in international retailing. J Econ Geogr 2017; 17 (3): 685-707 is available online at: https://doi.org/10.1093/jeg/lbw045. 


\title{
Dissecting Embeddedness in International Retailing
}

\author{
Steve Burt ${ }^{1}$, Ulf Johansson ${ }^{2}$ and John Dawson ${ }^{3}$ \\ ${ }^{1}$ Institute for Retail Studies' University of Stirling, Scotland. Contact author \\ ${ }^{2}$ Centre for Retail Research, Lund University, Sweden \\ ${ }^{3}$ Institute for Retail Studies' University of Stirling and University of Edinburgh Business \\ School, Scotland
}

\begin{abstract}
Embeddedness, and its constituent types, has been employed as a conceptual framework to explain the processes of host market acculturation in retail internationalisation. The retail industry is not, however, a homogeneous business sector. Differences exist between retail sectors, retail formats and governance modes in how retail business models evolve and how a retail business operates in a market. These differing characteristics alongside the coercive, mimetic, and agency pressures arising from interactions amongst institutions, consumer market cultures and firms determine the emphasis placed upon different embeddedness types and how embeddedness occurs. Consideration of these factors allows us to "dissect" the generic embeddedness concept and gain a more nuanced understanding of the processes involved. A deeper understanding of the nature and process of embeddedness will support future studies using the concept across many economic sectors.
\end{abstract}

\section{Key words:}

Embeddedness; retail sector; retail format; governance; retail internationalisation

JEL Classifications: D21; F6; F23; L81; M16

Accepted for publication in Journal of Economic Geography, published by Oxford University Press 


\section{Dissecting Embeddedness in International Retailing}

\section{Introduction}

Economic geographers have used the global production network approach to explore the dynamic spatial and organisational relationships in the global economy (Coe et al., 2008). In the management literature, authors such as Ghosal and Bartlett (1990) have also drawn attention to the role of transnational networks through the application of inter-organizational network theory to the study of the multinational firm. Both of these approaches focus on the interconnectivity and interactions between a wide range of geographically dispersed actors and agencies both internal and external to the firm. Fundamental to these perspectives is how transnational firms and their associated networks are socially embedded within their respective socio-economic environments at a variety of spatial levels.

The concept of social embeddedness has been widely used in many disciplines as a way of addressing how market economies interact with social structures and behaviours. The original conceptualisation (Polanyi, 1944) has been developed by Granovetter $(1985 ; 1992 ; 2005)$ and Grabher (1993) to provide the basis for its application in a variety of economic and social contexts. Common to these approaches is an acceptance of the polymorphic nature and 'plethora of meanings linked with embeddedness' (Hess, 2004: p. 66) but there has been no attempt to dissect this polymorphism when applying the concept in a specific context. Our aim in this paper is to address this gap and to dissect social embeddedness in terms of its specific application to understanding the processes associated with a firm moving into new geographic markets. International retailing is considered a vehicle to illustrate how the concept of embeddedness, when used as a tool for empirical analysis, has the potential to contribute to our 
understanding of expansion processes in multinational service sector firms. This context further provides a response to the call to move beyond general discussions of social embeddedness and to ground the concept in specific social, economic and geographical structures (Taylor, $2000 ; 2005)$.

The embeddedness concept has formed the basis of important studies in international business (Oinas, 1998; Tzeng and Uzzi, 2000; Jones, 2008; Heidenreich, 2012a,b; Ferraris, 2014). Whilst existing studies of embeddedness in international corporate activity begin to identify particular characteristics of the types of embeddedness involved, they do not, however, attempt to dissect embeddedness in relation to the variety of business models evident across internationally operating firms. The case for using retailing as an exemplar of business sectors with multiple business models rests in the close and direct relationship between a retailer and the local socio-commercial environment. Retailing occupies a pivotal position between market driven production and socially constructed consumption, and the retail firm therefore plays a key role in establishing and managing the networks, relationships and transactions which allow products and services to be produced. distributed and consumed, and thus is central to embedding processes.

In the context of retail internationalisation, social embeddedness in the local market is an important aspect of market success. The term glocalisation has been used to describe particular approaches to the activities of international retailers by Matusitz and Forrester, (2009); Matusitz and Leanza, (2009); Matusitz and Reyers, (2010); Dupuis and Fournioux, (2006); and Chinomona and Sibanda, (2012), but in effect glocalisation is a part of social embeddedness. Whilst in a home market, the processes associated with social embeddedness evolve gradually, when a firm enters a new geographic market these processes have a stronger dynamic through knowledge transfers from the domestic operations, pro-active adaptions to the new market, and responses from social institutions (Goldman, 2001). An inability to generate social 
embeddedness is a contributory factor in the large number of failures of firms moving internationally, as illustrated in retailing by Alexander and Quinn, (2002); Burt et al., (2002; 2003); Palmer, (2004); and Christopherson, (2007). The importance of establishing social embeddedness in new markets therefore makes understanding the links between the processes of embeddedness and the characteristics of specific business sectors and business models of particular interest.

Consideration of differences across firms in the application of their business models allows us to address Beckert's criticism that "“embeddedness" characterises a general answer to specific problems without identifying the underlying problems themselves' (2007: p10) and the suggestion of Taylor (2005) that embeddedness theory 'needs not only to be unpacked, it needs to be more thoroughly tested against appropriate empirical evidence' (p82). We frame variety in business models as related to the products sold by the firm, the operational model used by the firm and the governance of the firm, and we use retailing to illustrate this framing and provide empirical evidence of the concept of embeddedness and its implementation in practice in new markets. Three questions are posed. First, does the retail sector, in terms of product, affect the processes of embeddedness: is the concept and its application different for different sectors such that the processes differ for a large grocery/general merchandise retailer such as Tesco, a large fashion retailer such as H\&M, and a large electronics retailer such as Media Markt? Secondly, are embeddedness processes affected by the operational format model of the retailer with embedding activities different, for example, for the convenience store, supermarket, hypermarket and vending machine? Thirdly, does organisational governance affect embeddedness with different processes present for example in franchise operations or voluntary chains compared to public companies? 
The paper comprises three sections. First we review the types of embeddedness that have been identified, particularly in international retailing, and their underlying relationships with institutional, consumer market and firm level factors. Secondly, drawing on examples, we consider the links between these types of embeddedness and the variety found within retailing between different sectors, formats and governance forms to dissect the polymorphic nature of the concept. Finally, we conclude by summarising the contribution of the study, and suggesting directions for future research.

\section{Types of embeddedness as related to international retailing}

From its initial formulation by Polanyi the concept of social embeddedness has been used in a variety of economic, social and political contexts. Reviews of the concept have been provided by Heidenreich (2012a,b), Beckert (2007), and Zukin and DiMaggio (1990) and of Polanyi's work by Peck (2013), and Block and Somers (2014). Whilst the social embeddedness concept has general relevance for insights into the relationship of firms to their social environment (Taylor 2005), our current discussion and application of the concept is limited specifically to the processes that take place when a retailer becomes established in a market outside its home country. We are acutely aware of a substantial body of research that develops, reconceptualises, revisits and attempts typologies of social embeddedness in different contexts (for example Andersen, 2013; Geels, 2014; Ferraris, 2014; Hoenen et al., 2014; Laud et al., 2015; Wu and Pullman, 2015; Brailly et al., 2016) but we do not review these in detail due to both space constraints and also our deliberate focus on retailing as an example of the way the business model of the firm, in general, affects the nature of embeddedness. Building, therefore, on the directly relevant work within economic geography of Hess (2004), Wrigley et al., (2005), Tacconelli and Wrigley (2009), Coe and Lee (2006, 2013), Lowe and Wrigley (2010), Kotelnikova (2013), Sirait (2014), Wood et al., (2014) and Buckland-Wright (2016), that are central to the geographical and retail considerations of embeddedness, we start with the 
typology of Hess that distinguishes societal embeddedness, network embeddedness and territorial embeddedness as three inter-related components of social embeddedness.

Societal embeddedness relates to how the history, culture and institutions of the firm's market of origin has enabled or constrained the emergent business model that is used in a new market. In his seminal paper, Hess (2004: p176) likens societal embeddedness to the 'genetic code' of the organization although this implies an immutability which we would challenge. The genetic code analogy implies both a more deterministic and a static concept than we believe to be useful for analysis of the very dynamic internationalisation processes in retailing. The internationalising firm evolves within a particular societal context and is influenced by the historic, prevailing, and changing, institutional norms of behaviour and regulatory frameworks. The norms may be general to the whole of the society or may be industry (retail) specific. These external factors and the internal agency of the organization, together, shape organizational values and culture, and underpin the corporate vision and corporate behaviours and so generate an evolving societal embeddedness. As well as being 'where an actor comes from' (Hess, 2004: p176) societal embeddedness is also about how the actor responds to that home environment. Our interpretation extends that of Hess with societal embeddedness viewed as an attribute of the organisation, formed by societal interactions and transferred (and evolving) as the firm moves to new markets.

Network embeddedness relates to formal and informal inter- and intra-organizational networks that the firm negotiates in order to operate in the host market. In retailing, significant networks exist for procurement of goods and services, with public agencies including government, and for knowledge flows in the firm. 'The type of network in which an organization is situated defines the potential opportunities available to it, while its location in the network and the quality of its relationships with other actors demarcate its capacity to access these opportunities' (Sacks and Uzzi, 2000: p96). The networks may, but do not need to be spatially 
anchored in the host market but the activity of the firm in this market has to be a part of the network. Kotelnikova (2013) shows institutional and power relationships being used differentially by different agents in negotiations in the networks. Hess (2004) points to the 'architecture, durability and stability' (p177) of individual relationships and the 'the structure and evolution of the network as a whole' (p177) as the determinants of the extent of network embeddedness. Within the retailer there are often networks of stores and distribution centres in the host market and also networks that involve activity in other national and transnational networks. Negotiating internal and external network relationships is essential to generating embeddedness.

Territorial embeddedness relates to the degree to which an organization becomes "anchored" in a particular space. For the internationalising firm territorial embeddedness is linked to the ongoing process of societal embeddedness within the host market. In retailing, this includes reactions to the local consumer culture and markets, real estate and land use planning legislation (Wood and Reynolds, 2014), operating requirements, labour regulations (Sirait 2014) and logistics and supply chains (Taconelli and Wrigley, 2000). Many of the studies of international retailing have focused on these territorial characteristics (for example Bianchi and Arnold 2004; Matusitz and Leanza, 2009; Goldman. 2001; Minahan et al., 2012), particularly the consumer culture and institutional structures to which retailers have to respond in order not only to have permission to operate but also to operate profitably. Comparing the different types of embeddedness Coe et al., (2012: p27) state, 'This is not to say that home country embeddedness' (societal embeddedness in our terminology) 'in particular is unimportant, but that in certain sectors, meeting the various needs of different national market places is the more significant influence on corporate strategies and structures'. Lowe et al., (2012) in their study of Tesco in the USA place territorial adaption processes in a capability framework, suggesting that firms 'have two options, either to reconfigure routines in the new market context so that 
they reflect capabilities that reinforce the organization's identity or to combine variants of existing identity with new elements from the external context that implies reconfiguring capabilities and developing entirely new ones consistent with the new market' (p1022). Territorial embeddedness results from taking account of local market societal norms and the way they change and using existing or new capabilities to become established. In generating territorial embeddedness, however, retailers may also influence the territorial characteristics to which they respond and over time will develop subsidiary specific advantages of the form identified by Ferraris (2014).

The concept of social embeddedness, and its three types as identified by Hess, emphasises the dynamic nature of the relationships between the market and its social environment and this makes it particularly relevant to considerations of international retailing. Emphasising this dynamism Burt et al., (2016) suggest, in respect of international expansion, "For retailers these three categories each have a dominant process by which embeddedness is executed: processes of transfer in societal embeddedness, negotiation in network embeddedness and adaption in territorial embeddedness." (p25) Each of the three types of embeddedness have their own characteristics but nonetheless interact with each other in the totality of international retailing activity. Societal embeddedness reflects aspects of network and territorial embeddedness and vice versa. The interactions between the different types of embeddedness are often firm and place specific being different for different firms, different markets and different sectors. To gain a better understanding of the nature of these interactions it is useful to consider the foundations of the total concept. Societal, network and territorial embeddedness in international retailing, emerge and evolve from the relationships amongst institutions, consumer markets and firms.

It has long been advocated that embeddedness processes are strongly influenced by institutional systems which can place substantive constraints on how embeddedness occurs locally 'because 
the institutions are embedded in a culture in which their logics are symbolically grounded, organizationally structured, technically and materially constrained and politically defended' (Hollingsworth and Boyer, 1997: p2). In respect of international retailing there is clear evidence of the influence of institutions in the ways that a retailer operates differently in its various markets. The formal institutions of the legal system, the national and local political systems and the real estate and land use planning regulations (Wood and Reynolds, 2012; 2013; 2014) are particularly relevant. Local institutions can have a substantive impact on networks. Yeung (2006) points out that, 'A network link that crosses international borders is not just another example of "acting at a distance" it may also represent a qualitative disjuncture between different regulatory and cultural environments' (p319). Institutional theorists suggest that institutions exert coercive pressures that increase the likelihood of homogeneity of organizational structures and, hence in our analysis, the processes of retailer responses. Thus for example, Siriat (2014) has shown that employment relations outcomes in multinational food retailers in Indonesia are influenced strongly, almost exclusively, by the regulatory and institutional framework. Whilst retailers can exert some influence on these systems their options are very limited (Faulconbridge and Muzio, 2015). Institutional attributes, which are external to the firm, therefore act as major influences and constraints particularly on the territorial and societal embeddedness of international retailers generating interactions between the processes operating in different types of embeddedness.

Alongside the formal institutional systems influencing embeddedness, there are the cultural and social structures associated with the consumption practices of consumers. These may be long established cultural traditions or can be recent social fashions. Again these structures are external to the firm but can be influenced by the firm. Whilst the influence is particularly strong with territorial embeddedness, the social and cultural values of consumers also interact with societal and network embeddedness. For the internationalising retailer there is likely to be 
higher uncertainty in the foreign commercial environment, than in the domestic market, arising from interactions with the consumer market. It can be argued that competition between international retailers becomes subjected to mimetic pressures from the consumer market, as retailers copy each other in the ways they interact with consumers when the dominant consumption processes are different from those that are well known to them. Unlike the political and legal institutions, however, the cultural and social structures of consumers are ambidextrous in both influencing and constraining the retailer (Jackson, 2004) and also being influenced and changed by the retailer. This active shaping by the retailer of the market and consumer interactions results in market driving by the retailer (Kumar, 1997; Tarnovskaya et al., 2008; Elg et al., 2012) in which the retailer attempts to change and shape relationships with consumers (Dawson, 2013) in order to gain advantage through using resources and capabilities unique to the retailer.

A third group of factors that link directly to embeddedness processes and the interactions amongst the types of embeddedness, comprise the rules, resources and managerial capabilities existing within the firm. These firm level factors are strong stimulants for the processes required to implement embeddedness in international retailing and relate to societal, network and territorial embeddedness. It is, however, not only the influence of these factors on the retailer involved in internationalisation that creates embeddedness. The nature of retailer competition, means that comparable factors influencing competitors and other network organisations, external to the internationalising retailer, are also relevant. Managerial agency generates pressures for heterogeneity in the patterns of embeddedness exhibited by similar retailers operating in the same foreign market. Innovation, resulting from merging unconnected resources andlor accessing new external resources to adapt to the commercial environment, is an important process in embeddedness, and the source of and implementation of innovation rests within the retailer. The problem and paradox of simultaneously exploiting globalization 
and territorial advantages has been a cornerstone of strategic management since Bartlett and Ghoshal (1989) developed their typology and these difficulties continue to be evident in present day international retailing. Thus for example Walmart and Carrefour operate in different ways from each other in China (Siebers, 2011; 2012; 2016; Gamble, 2011; Chuang et al., 2011; Cao and Pederzoli, 2013; Shi and Au-Yeung, 2015) and H\&M and Inditex exhibit different forms of embeddedness in the USA (Schröder, 2014; Lopez and Fan, 2009). Firm level factors are thus of considerable importance in generating interactions amongst the three types of embeddedness.

The influences and interactions amongst these institutional, consumer market and firm level networks and relationships are complex and most importantly dynamic. By developing a correspondingly dynamic view of societal, network and territorial embeddedness the retailer responds to and creates a commercial environment which allows exploitation of the specific capabilities of the retailer through its business model. Fundamental to the business models of retailers are specificities of retail sector, retail format and governance. Thus there is an expectation that societal, network and territorial embeddedness will involve different processes and have different outcomes that are influenced by the sector, format and governance of the internationalising retailer.

\section{Sector, format and governance influences on embeddedness}

The widespread use of internationalisation as a retail growth strategy has increased the importance for retailers of understanding embeddedness. The internationalisation of retail operations is growing in all parts of the world, in all retail sectors and involves different formats and forms of governance. Deloitte in their annual "Global Powers of Retailing" series have been monitoring the international activities of the world's largest retailers over the past two decades. Whilst, in 2014, 83 of the largest 250 retailers still only traded in their domestic market, this has fallen from 107 in 2005, and the majority of these firms can be found in the 
large domestic markets of North America and Asia Pacific. The average number of markets in which the largest 250 retailers trade has risen to 10.4 in 2014 and international sales account for over $23 \%$ of total sales (table 1). In Europe, partly reflecting the relatively small size of domestic markets and proximity of international opportunities, the spread and significance of international retail activity is at higher levels.

\section{INSERT TABLE 1 HERE}

Sectoral differences in retail internationalisation are also evident. The average number of countries in which apparel and accessory retailers in the Deloitte Report operate is 26 and only $14.6 \%$ are involved solely in their domestic markets, compared to 5.3 countries and $41.3 \%$ for FMCG retailers. Franchising can be used to generate rapid internationalisation in apparel retailing. The FMCG sector average disguises a mix of operators, with many of the largest European grocery retailers present in multiple markets using different formats (Deloitte, 2016). Although useful in showing the general trend of increased internationalisation and broad sectoral contrasts, the average values have to be seen in the context of a skewed distribution with many firms present in 2-5 markets and a small number operating in over 80 countries. The conclusion, however, is a growing number of retail firms are involved in international retailing, operating across a range of retail sectors and through a variety of business models and formats, originating from and operating in diverse market contexts.

The heterogeneous nature of the retail sector generates, we argue, considerable and growing variety in the processes and practices of embedding retail operations in a non-domestic market. Considerations of the characteristics of the retail sector in which the firm operates, the retail format(s) through which it trades, and the governance form employed within the host market all have implications for embeddedness in international retailing.

\subsection{Retail Sector Characteristics}


Retailing is not a uniform economic sector. The broad sectoral categorisation of retailing by commodities sold is not simply a statistical convenience for economic reporting but each of the different categories of retailing has their own characteristics. As such the fashion and apparel retailing sector is different from the food and grocery sector or electronic and entertainment sector or furniture and furnishing sector, etc.. Whilst individual retailers design and operate their firm specific business model, the different retail sectors exhibit generic processes and operations that generate broad parameters for firm level activities. The three types of embeddedness therefore have different manifestations as retailers in the different sectors develop international operations

Embeddedness in the food and grocery sector has been the primary focus of research to date, with authors identifying the processes generating societal, network and territorial embeddedness. Embeddedness in a market derives from the retailer's interactions with the societal institutions and consumer culture that have shaped societal embeddedness in its home market. Thus Aldi's societal embeddedness in German consumer culture, institutions and society, and Walmart's and Dean and Deluca's societal embeddedness, in different ways, in American society and culture, provide the starting point for their respective societal embeddedness in foreign markets. One outcome of societal embeddedness in the home market is the establishment over decades of operation of corporate operating procedures which underpin the way the retail business functions. Rogers et al., (2005) noted that Tesco exported many of its domestic operational processes into Hungary and Slovakia and concluded that although making some local market adaptations, mainly related to developing a local customer focus (an example of the interaction of societal and territorial embeddedness), these were within a framework of established global corporate processes. When internationalising, Lowe et al (2012) term this as the 'transference' (p1045) of a capability. Even when transfer from the domestic context is involved there is, however, still a requirement to continuously develop the 
embedding activity (Lampel and Bhalla, 2008) in both home and host markets. As food and grocery retailing is essentially a high volume, low margin activity, managing the very large number of individual product items, co-ordinating the large number of suppliers, and, often, rapidly creating a store network when internationalising means that the transfer of standard operating procedures generated as part of home country societal embeddedness becomes the starting point for societal and territorial embeddedness in a host country.

The development of new negotiated networks of food procurement and supply chain logistics illustrate network embeddedness in the food and grocery sector. Challenges arise in new host markets from differences in supply chain structures, capabilities and behaviours, and in merchandise management and logistics practices, across markets (Fernie, 1995; Paché, 1995; Endo, 2014). There are several examples drawn from the experiences of British food sector retailers as they have sought to negotiate or renegotiate supply networks as they embed themselves in foreign markets - for example, Sainsbury (Shackleton, 1998), and Tesco (Lowe and Wrigley, 2010) in the USA, and Tesco in Asia (Coe and Hess, 2005; Coe and Lee, 2013; Buckland-Wright 2016). Network embeddedness involves the negotiation of new networks, and potentially the creation of networks, for example for products requiring different temperatures (Wang et al., 2013) or negotiation with state owned firms in China (Jiang and Prater, 2002) or for hydroponic vegetables in the Thai market (Rungfapaisarn 2012). To generate network embeddedness in emerging markets Reardon et al., (2007) suggest that food retailers should 'undertake 'proactive fast-tracking strategies' to alter the endogenous 'enabling conditions' of entry and growth' (p425). This may involve 'a shift from using spot markets to coordinated supply chains' (Reardon et al., 2012: p12335), and the development of logistics support for items requiring different temperature (frozen, chilled, ambient) regimes. These are aspects of network embeddedness unique to the food sector. 
Local food consumption cultures require that retailers in the food and grocery sector adapt their product categories, the items on sale, and in some instances, how and when they are sold. Territorial embeddedness affects the full range of products with adaptions of ranges including product branding to meet local tastes and consumption. There are many implications of assortment adaption with adaptions to category and pricing structures and promotional activities being necessary. Examples from Wal-Mart and Carrefour in Japan are provided by Aoyama (2007), and in China by Chuang et al., (2011). Similarly, Kim (2008) and Gandolfi and Strach (2009) attribute Wal-Mart's failure in South Korea to a failure to respond to the prevailing consumer culture, in contrast to Tesco which was perceived as localising its products, sourcing, and customer engagement (Coe and Lee, 2006). Territorial embeddedness occurs through not only retailers adapting to the consumer but also through consumption and behaviour changes encouraged by the retailer (Coyle, 2006). The difficulties experienced by western food retailers in China have been attributed (Chan, 2011; Herring et al., 2012; Huang and Liu, 2011) to an inability to fully adapt to local consumer demands, local institutional requirements and local managerial styles, compared to firms from other Asian markets. Where this occurs it is a failure of the firm to generate territorial embeddedness.

The operations of the apparel and footwear sector of retailing differ from the food and grocery sector in many ways including having higher gross margins, almost total control of branding by the retailer, different locational requirements, smaller product ranges and fewer categories, products with longer store life but with shorter life cycles, lower capital requirements and less frequent consumer contact. As a result, the nature of embeddedness for international retailers in this sector has specific characteristics, several of which do not affect other sectors. The process of societal embeddedness requires synergy between the host market consumer values and the brand values that constitute the specific differentiator of the retailer. This is evident at all market positions from Primark at the value end of the market to H\&M and Inditex (Bonache 
and Cervino, 1997; Lopez and Fan, 2009) through to the luxury brands (Wigley and Moore, 2007). Moore and Birtwistle (2004) and Tokatli (2012) in their studies of Burberry, with its quintessential British design style, point to the core role of the brand, entailing tight central control over brand marketing, brand identity and communications, as a vehicle to transfer the business model to foreign markets. The brand is unique to the retail organization and represents the design style and philosophy of the retailer as articulated through the products, store design and associated communication messages. Unlike the food and grocery sector, in apparel and footwear societal embeddedness involves an active interface between the retailer and the customer, whereas in the grocery sector territorial embeddedness and adaption processes characterise and shape the consumer interface.

Network embeddedness is important for the apparel and footwear sector with the presence not only of widely discussed integrated network ties, as in the case of Inditex- Zara (Hellier, 2001; Ferdows et al., 2004) but also a variety of other, more transactional, direct sourcing arrangements with manufacturers and trading houses through agents (Gibbon, 2001). The presence of multiple approaches to sourcing within an international apparel and footwear retailer is somewhat different from the grocery sector where localised embedded ties often characterise the network processes. As with grocery, however, network embeddedness is not static and as the international portfolio evolves, apparel retailers review their network ties (Tokatli, 2008; Runfola and Guerscini, 2013). Whilst many of the generic embedding processes associated with the supply chain are similar for grocery and apparel, there are obvious sectoral differences in the techniques of stock renewal and replenishment, logistics and transportation. Also, in the apparel and footwear sector, retailers with multiple brands may seek to cluster these locations to gain economies of scope across the brand portfolio and exhibit a specific form of network embeddedness in their negotiations for store locations. Inditex, for 
example, when expanding into new shopping centres often seeks to locate branches of their various brand formulae within sight of each other.

In the apparel and footwear sector the processes associated with territorial embeddedness are less prominent than in food and grocery, although aspects of the product range such as colours and sizes may need to be adapted (Frasquet et al., 2013) and some adjustment may be made to communication methods. Marks and Spencer's experience in China required a changed assortment and sizing (Waldmeir, 2009). Brands, store formats, and brand messages are typically standardised and transferred, as they encapsulate the essence of the retail proposition, although interactions between sales personnel and customers can be used to generate territorial embeddedness as customer service is sensitised to local social and cultural norms. Consumer expectations of in-store and after-sales service differ across markets. Again there is a distinction with the grocery sector where range adaptations are essential and self-service is common. Importantly also is the difference in scale of investment required to establish multiple apparel stores compared with the larger stores in the grocery sector and the consequential impact on the sunk costs within the financial aspects of business models.

In the electronics and entertainment sector product manufacturers are more powerful in the distribution chain than in other retail sectors and this affects the ways retailers become embedded in new markets. The retailer's brand is generally weaker than that of the manufacturer and few retailers in the sector have a strong enough brand culture that can, in itself, form the basis for embeddedness in a new market. One of the reasons for the lack of success of Best Buy and Media Markt in China was the weakness of the retailers' brands for Chinese consumers compared to the strength of the manufacturer brands (Wang, 2014; Amankwah-Amoah et al., 2013; Reddy, 2013). Also strong growth of the on-line channel in the electronics sector differentiates this sector from other major retail sectors and impacts on all three types of embeddedness. 
As a result of these specific sectoral characteristics, the processes of societal embeddedness in electrical and entertainment retailing relate primarily to systems associated with major operational functions, for example management control systems. Network embeddedness involves negotiated joint decisions with manufacturers over the distribution network and associated logistics and services. With manufacturer control over product branding and development the opportunities for territorial embeddedness are limited to localised sales initiatives, for example promotional activity, the bundling of products with services, and localised service support activities. For example, Courts Asia differentiates itself through financial services - offering credit which allows low income consumers in South East Asia to purchase products. In 2015 credit accounted for $73 \%$ of sales in Malaysia and $89.5 \%$ in Indonesia compared to $17 \%$ in the more affluent Singapore market.

Exceptions to this generalised pattern are present when there is quasi-vertical integration in the sector, for example with Apple, and to a growing extent Samsung. In these cases, it is the manufacturer which has become a retailer to maintain control over the supply chain, brand distribution and communication. Societal embeddedness increases with the transfer of brand and image, with substantive aspects of store design, corporate culture and customer services being linked to the core brand identity and transferred as an aspect of societal and territorial embeddedness. Local influences through territorial embeddedness are reduced as a consequence and market driving activities dominate. As the degree of vertical integration increases there is a trade-off between societal and territorial embeddedness.

In other retail sectors there are also specific characteristics that affect the nature and types of embeddedness that are developed by the retailer. The differences in how retail sectors generically function reflects the differing influence of coercive, mimetic and agency pressures arising from the underlying institutional, consumer market and firm level networks and interactions. The role, nature and form of these pressures varies from sector to sector - being 
different in apparel and footwear or electrical and entertainment from those found in the food and grocery sector. These have implications for embeddedness and the inter-relationships and processes associated with societal, network and territorial embeddedness.

\subsection{Retail Format and Formula Characteristics}

Retailers compete with each other for consumers through a "place of transaction" (Dawson and Mukoyama, 2014), typically a store but with the growth of on-line and mobile retailing other "places" are now available. As with different retail sectors, different "places" or formats exhibit different characteristics which have implications for various aspects of embeddedness. It is useful to distinguish between the concepts of the retail format, retail formula and the retail brand. The retail format may be a physical format or a virtual place and is a distinctive bundle of distribution services arising from a set of underlying business processes and activities (Betancourt, 2004). Each format has a generic business model. The way individual retailers perform the processes and activities in the business model creates a company specific retail formula - in effect the interpretation and operation of a format by a retailer. The formula is effectively the retailer branded format. Consequently, whilst Aldi, Lidl, Netto, BIM, Dia and Biedronka all operate a limited line discount store format in the grocery sector, each firm presents a different interpretation of this format to the consumer, and to some extent these different interpretations reflect the domestic societal embeddedness of the firm. These different interpretations are then communicated to the market through a brand, which allows consumers to identify each of the different retail formulae. The brand encapsulates consumer perceptions and experiences of that formula through the image and identity that the brand conveys. Formats, formulae and brands are products of the prevailing socio-economic context and time, but are not static representations. Organisational learning, often arising from understanding the different processes of embeddedness, at a range of spatial levels, ensures that formats, formulae and brands morph and evolve. 
The store format is an established concept in retail research (Zentes et al., 2011) and operational practice. Alongside the firm, the format is the unit of analysis in most research on retail internationalisation and in many markets is a unit of data collection as well as line of trade. As the "place of transaction", where the consumer comes into contact with the retail firm, the retail format is typically the visible manifestation of retail internationalisation. As such it plays an important role in embeddedness, particularly societal and territorial embeddedness. Generic store formats, such as the department store, the supermarket, and the boutique, are recognised as such through a series of common characteristics relating to location, physical characteristics, service provision and market proposition. Locational characteristics include the format's relative location to consumers and other retailers, for example in- or out-of-town, at a transport hub or shopping centre etc, and the associated density of a store network over a larger space such as an urban area or region; physical characteristics include scale which relates to the size of the store and the basic configuration of space which determine the sales area available and in turn the volume of merchandise that can be offered plus the layout of the store; service provision incorporates the services on offer, including ancillary services to support the shopping experience and staff deployment and capabilities; and store environment reflects the atmosphere and "feel" of the format, and the operationalisation of the merchandise offer - mix, depth, variety, brands, price, presentation etc. As with considerations of the retail sector, these generic store formats and their associated characteristics have implications for our understanding and application of societal, network and territorial embeddedness in different markets.

Individual retail formats, as an output of a business model and associated interactions, comprise discrete operational processes, routines and physical attributes. Initially determined and evolved within the societal setting of the market of origin, the format may often provide a source of distinctiveness and competitive advantage relative to existing formats and formulae 
in the new market (Swoboda and Eisner, 2013; Schröder, 2014). The hypermarket format was an integral element in the initial international activities of French grocery retailers whilst the department store was the format employed by the Japanese in early internationalisation activities within Southeast Asia. Similarly the distinctive IKEA store and the flagship and boutique stores of Louis Vuitton are the means by which these retailers interact with customers in new geographical markets. The format epitomises and encapsulates the retailer and its offer, so in some circumstances the format and formula form part of a market driving strategy, in others the key question is to what extent the format and formulae need to adapt and evolve. The general approach is to seek to replicate the format and formula in the new host market and processes of transfer of operational practices, brand concept, store atmosphere, service ethos, etc are common, although often format specific (Gamble, 2010). In cases where the core distinctiveness of the format is closely associated with a formula and in particular a strongly branded formula, as in flagship stores, the brand vision is the key dimension which retailers seek to replicate through the format and formula for example Louis Vuitton, Apple, and Harrods. For internet retailing, which is internationalising as local regulations allow, the underlying business processes that are generally linked to an established and recognisable brand formula, whether in a pure e-retailer (for example, Amazon, e-Bay, ASOS) or in an omnichannel retailer (for example, Bed Bath and Beyond, le Coq Sportif, and Top Shop) is the source of replication.

The processes of network embeddedness associated with the format and formula depend on interactions and relationships with multiple agents. Location is a significant variable in the format so relationships with property providers (Wood and Reynolds, 2012; 2013; 2014) are important considerations in network embeddedness. Real estate markets work in different ways in different markets. The availability of sites, property ownership and rental and leasing arrangements require knowledge networks to ensure format viability within the 
internationalising retailer's business model. The formula is a created environment so relationships with the designer of the formula environment also support network embeddedness. Formats and formula carrying large produce ranges and offering specific service functions such as department stores, hypermarkets and non-food warehouses (DIY etc) will require the negotiation of relationships to enable network embeddedness with the supply chain infrastructure in a new market - both of national and private brand providers - and employee development to ensure engagement and buy-in to potentially new work practices, working hours, attitudes and behaviours (Gamble 2006). If a multi-channel offer is part of the trading proposition then relationships with third party delivery networks are crucial.

Adaption of some elements of the format and formula proposition will emerge as territorial embeddedness is sought. Consumer acceptance of formats and formulae vary depending on established consumption patterns, consumer behaviours and market structures. Not all formats are accepted in every market and some formats persist in some markets whereas they have declined in others. For larger formats, urban structures and associated government planning policies may require some adaption to format size and structure, for example multi-level hypermarkets in Southeast Asian cities. Land use planning policies and how these are targeted at format types illustrate how territorial institutional factors have different effects on the different formats. Territorial embeddedness results in product range, communication and service adaptations, for example in the addition of wet market-style environments in hypermarkets and air conditioning units in electrical warehouses in Southeast Asia. Metro, for example has developed a range of localised versions of the standard Cash and Carry format for its operations across the world to reflect localisation strategies as territorial embeddedness is sought and the delivery service offer and associated small shop support packages also vary to reflect the local market context (Burt, 2014). Similarly, the supermarket and convenience store have evolved in different ways in different parts of the globe. 
The large variety of formats and formulae that derive from the different business models of retailers is one of the unique characteristics of retailing in comparison with other economic sectors. They are major components of inter-firm competition in retailing and as such are an important contributor to the overall embeddedness of the retailer in the market. The influence of institutional, consumer market and firm factors is evident across the different types of embeddedness as they interact with different formats. Institutional factors associated with landuse and urban planning affect the extent and the processes in which the large floorspace formats can become territorially embedded. Market and consumer culture issues, such as the frequency of shopping trips and composition of baskets, relate strongly to network embedding of locality orientated formats, for example convenience stores. The influence of firm resources and capabilities can be seen in the decisions on how to societally embed brand orientated formats, for example boutiques and in-store concessions. The inter-linkages between the three types of embeddedness is evident through decisions relating to formats and formula as retail firms internationalise, as ultimately these represent the "place" where consumers, markets and firms meet and interact.

\subsection{Governance Forms}

Governance is an important component of the business model of a retailer and influences strategic and operational decision making. The various forms of governance will have distinctive influences on the processes of embeddedness in international retailing. There is a tension between the transfer of a strongly developed governance mode that perpetuates features of domestically derived societal embeddedness and an approach to governance that draws on local market factors so emphasising territorial embeddedness. The involvement of a local partner in some form, for example in a joint venture or franchisee relationship, will impact upon the negotiation of network relationships and territorial embedding processes. Governance modes are not static, and internationalising retailers employ different modes over 
time and space as they expand and seek to become more deeply embedded in the local host market (Peterson and Welch, 2000; Picot-Coupey, 2006; Swoboda, et al., 2015).

The governance form may in itself be an integral part of the business model, so efforts are made to transfer and replicate arrangements in the host market as much as possible. Spar and IGA are voluntary chains and Intersport is a retail buying group and these are embedded governance characteristics that are replicated as these retailers internationalise. Other companies that employ dual ownership modes, where the store managerlowner takes a minority stake in the business for example Media Mart and Specsavers, similarly look to replicate this arrangement with partial ownership believed to incentivise operational performance at the local level. These "shared" governance forms have evolved as part of the organizational structure and agency arrangements of the retailer as it has emerged within its domestic societal setting and the processes of network and territorial embeddedness with these governance types will usually involve processes that transfer established rules of governance.

In some markets and for certain retail sectors the governance mode may be imposed by institutional constraints. The long running debate over FDI rules in India and foreign ownership restrictions in parts of the Middle East force retailers into specific governance forms, whilst in China the political structure of the market requires the establishments of multiple subsidiaries with different trading partners in different regions and cities (Siebers, 2012; Wang, 2014). In these cases, the prevailing formal institutional factors determine, in large part, the form of governance and has consequences for negotiating network embeddedness and adapting for territorial embeddedness.

There are a number of governance forms commonly found in international retailing which impact upon embeddedness processes. Privately owned companies still persist within retailing. Major grocery chains such as Aldi and the Schwarz group (Lidl and Kaufland), apparel and footwear retailers such as Arcadia (Burton, TopMan, TopShop etc) and IKEA provide 
examples. Often driven by the entrepreneurial vision and values of the founder(s) this form of governance typically relies on self-funding expansion and entrepreneurial capabilities are important in international embedding. With no formal requirement to make full financial disclosures around operational performance, return on investment expectations tend to be more flexible than many other governance forms allowing a retailer to remain in a specific market for an extended period of time whilst embeddedness occurs. As the locus of governance, authority and control in privately owned retailers is usually retained in the domestic market, there is a tendency to focus at least initially on what the retailer brings to the market and the transfer of the domestic business model. As expansion takes place in the new market, however, adaption of operational practices to gain territorial embeddedness can be undertaken without the scrutiny of external financial institutions and may occur as the retailer proclaims standardised practices in order to gain from the domestic reputational brand awareness. For example, IKEA and Aldi both suggest that they transfer their operations and values unchanged when developing in new markets, but the reality is that both undertake adaptions to the local market and consumption behaviour in order to become territorially embedded. In the case of public (listed) companies, the sourcing of capital from financial markets brings with it heightened stakeholder scrutiny and analysis, often generating expectations of rapid returns on investment in both home and overseas markets. The pressure on Tesco to make a speedy return on its American venture provides one example. These expectations create pressures and shape behaviours and decisions as embeddedness is required rapidly to satisfy the external stakeholders (de Jong et al., 2007; Wood et al., 2016).

Other governance and expansion modes involve interaction and engagement with local market partners through mechanisms such as affiliations to voluntary chains or buying groups, joint ventures and franchising. Palmer et al., (2010) and Owens et al., (2013) suggest that whilst the joint venture approach is motivated by the desire to understand and conform to existing market 
norms of behaviour, it also provides the scope to negotiate and seek to influence existing norms. Complementary expertise is an important driver in a successful joint venture partnership. Often in international retailing the most sought after local market expertise is in the field of real estate including the relevant political and regulatory networks. This expertise assists in the processes of negotiation and adaptation to achieve network and territorial embeddedness. Clarity of responsibilities and matching of ambitions is however a core pre-requisite of joint ventures, otherwise tensions may surface between partners, as evidenced by the dispute over strategic direction between Carrefour and Sabanci group in Turkey and Casino and the Diniz family in Brazil. It is not unusual for an initial joint venture partnership approach to move towards either public or private ownership once a venture is established as a degree of network and territorial embeddedness is achieved.

Franchising as a governance approach in retail internationalisation has grown in popularity in many sectors and as retailers "in-fill" existing market spaces with smaller store formats. Once established in a market, franchising can be used as a means of rapidly establishing local market coverage and mitigating against management capacity challenges, allowing expansion with relatively low levels of resource and sunk costs. Quinn and Doherty (2000) argue that successful international franchising requires a strong societally embedded domestic business model which can be transferred into other markets, but also relies on high levels of network and territorial embeddedness through local partners to achieve success. One potential issue with franchising (and other partnership forms) is that depending on the contractual conditions, the local partners may leave the network at some stage. This provides an incentive to ensure that the partnership delivers benefits for both partners.

The choice of governance mode has a number of implications for embeddedness and the associated processes and activities. First, the locus of authority and the balance between centrallcore and local level decision making. This influences perceptions of the local host 
market and the scope for transferring, negotiating and adapting the retail business model. Some business models may inherently require higher degrees of local entrepreneurship capabilities to maximise performance, whilst for others success comes from adhering to established company processes and procedures. Second, governance mode impacts upon the extent, nature and form of knowledge transfer - both from the internationalising company and the host market. Different forms of organisational learning have been identified in retail internationalisation (Dawson, 2003; Palmer and Quinn, 2005; Jonsson and Elg, 2006). Organisational learning has both cognitive and behavioural dimensions typically leading to adaptions to routines, practices and procedures with consequent implications for the processes of embeddedness. Finally, governance forms have implications for resource commitment not just of capital but perhaps more significantly managerial expertise. Large networks of stores need access to extensive talent pools. International store networks can be extensive and typically involve different store formats in different countries - Walmart, Carrefour and the Schwarz Group now operate between 11,500-12,200 stores across 28, 34 and 26 markets respectively, whilst Inditex trades through 6,900 stores in 88 countries and H\&M 3,900 stores in 61 countries. Cultural differences between markets in the attitudes and approaches of staff to managerial practices further complicate the ability of an internationalising retailer to embed itself in a host market (Hurt and Hurt, 2005; Gamble, 2006; 2010). These implications create a balance between the transfer, negotiation and adaption processes in societal, network and territorial embeddedness.

\section{Conclusion}

The role of transnational networks in the global economy has attracted the attention of economic geographers and management academics in an attempt to explain the workings of industries and firms. These approaches recognise that networks, firms and associated activities and behaviours are embedded within the territories within which they operate. Retailing, by 
its very nature, is a highly networked industry and as such provides an appropriate focus for developing our understanding of the role, nature and implications of social embeddedness, in many of its manifestations, on the organisation of economic activity.

In this paper we contribute to the application of the embeddedness framework by pointing to the underlying pressures and features which shape different business models of economic activity and in turn impact upon the processes and activities associated with embeddedness. By 'dissecting' the framework in this way we suggest that a more nuanced consideration of how firms behave and operate within the international marketplace can be achieved. Retailing has been used to provide specificity to the dissection of the concept of social embeddedness in a way that meets Taylor's (2005) call for the testing of the embeddedness concept with empirical data. Retailing has been the exemplar used in this paper but all sectors of economic activity comprise organisations, usually firms, with business models that are central to the concept of social embeddedness.

We have argued that whilst the current academic discussion of embeddedness has made valuable contributions to understanding retail internationalisation, the conceptualisation needs to be moved on from considerations of the types of embeddedness per se to encompass the implications for embeddedness of the diverse range of business models found in the retail sector. To achieve this, we show that there is a need to incorporate consideration of the characteristic features of different retail sectors, retail formats and governance modes, and of the underlying pressures from institutions, consumer markets, and the firm itself. These industry specific dimensions, we believe provide opportunities and constraints for the processes and activities involved in societal, network and territorial embeddedness as retail firms internationalise. The dissection of embeddedness in this way is one of the contributions of this paper. 
In empirical application of the concept it is necessary to consider first the nature of social embeddedness, for this we use Hess's threefold categorisation as a basis for development, and secondly the characteristics of the business models of firms that operate in the market. We disaggregate the business model into the characteristics of the product/service markets within which the firm operates, the physical manifestation of the operation of the firm, and the governance of the firm. In our retailing example these are the retail sector, the store format and the governance mode. Comparable dimensions are present in other industries enabling our illustrative focus on retailing to have wider applicability.

Like many industries, retailing is not a uniform economic activity. There are significant differences between retail sectors in how they are configured, behave and operate and how consumers interact with them. Differences exist in the frequency and nature of customer contact, the composition and behaviour of supply chains and the structure of the product ranges on offer. Similarly, although generic retail formats can be identified they differ in many ways, for example in locational requirements relative to customer flows, shopping environments and competitors, in the physical size and configuration of store units; and in the broad market proposition communicated through store environments. Finally, there is a great range of governance modes which determine several aspects of managerial agency relating to the location of decision making; degrees of authority and responsibility; local market knowledge and sense making; organisational learning capabilities; and access to financial and human resources. These sector, format and governance differences in business models are important considerations in understanding embeddedness in retail internationalisation.

The different characteristics and the processes of societal, network and territorial embeddedness are shaped and influenced by institutions, consumer markets and the firm. Formal institutions exemplified by the prevailing legal and political system exert largely coercive pressures on the processes of embedding the retail operation within the host market. 
These pressures push towards a degree of homogeneity in approach. Consumer market cultures reflect historically and socially rooted consumption practices and give rise to mimetic pressures as retailers tend to follow the strategic approach and operational behaviour of competitors. These pressures are ambidextrous in that the retailer may be driven by the market or may drive the market. Finally, the firm is not a passive entity, the internally determined rules, resources and behaviours of the firm act via managerial agency to provide pressures towards heterogeneous outcomes, as individual firms seek out innovative and distinctive approaches within the new market as a means of attracting customers and competing with established firms. The network of relationships between institutions, consumer markets and firms, and the sectoral, format and governance differences magnify and determine the emphasis placed upon certain embeddedness activities and processes as retailers internationalise. How a grocery retailer operating large store formats through a joint venture arrangement seeks to embed itself in a host market is different from the approach taken by a clothing and footwear retailer trading through boutiques and in-store concessions via franchising or licencing. These differences have implications not just for the process of embeddedness but also the capacity and capabilities of the firm. Consideration of these differences provides a more finely tuned and more dynamic interpretation of embeddedness.

The present study provides a basis for several areas of future study. Embeddedness processes, linked to the characteristics of the economic sector, the operationalisation of economic activity, and governance mode, evolve and over a period of time may be subject to considerable change. Longitudinal studies which encompass changes in these three dimensions are likely to provide deeper understanding of the dynamic aspects of embeddedness. The interactions amongst the types of embeddedness provides a second potential direction for research. In this paper we have pointed to some of the interactions but more research is needed to study the detail of these interactions, the ways they change and the relationships between structure of the sector and 
embeddedness. International retailers, of all sizes, are moving increasingly to operating in multiple sectors with multiple formats and multiple governance processes such that the embeddedness processes become more complex from the perspective of the firm. Exploring the extent to which knowledge about the different embedding processes is transferred within an international retailer is a further area of future research that could be based on the current study. Finally, whilst retailing has been the focus of this paper, the potential to consider more finely grained aspects of other industries, particularly the core dimensions of the sector generic business model and how these influence or are influenced by the processes of embeddedness, provides another opportunity for future research. 
Table 1: International Spread of Largest 250 Retailers

\begin{tabular}{|l|c|c|c|c|c|c|c|c|c|}
\hline $\begin{array}{l}\text { Region and } \\
\text { Country of } \\
\text { Origin }\end{array}$ & $\mathbf{N}$ & \multicolumn{3}{|c|}{$\begin{array}{c}\text { Average Number of Countries } \\
\text { \% Sales from Foreign Operations }\end{array}$} \\
\cline { 3 - 10 } & $\mathbf{2 0 1 4}$ & $\mathbf{2 0 0 0}$ & $\mathbf{2 0 0 5}$ & $\mathbf{2 0 1 0}$ & $\mathbf{2 0 1 4}$ & $\mathbf{2 0 0 0}$ & $\mathbf{2 0 0 5}$ & $\mathbf{2 0 1 0}$ & $\mathbf{2 0 1 4}$ \\
\hline Top 250 & 250 & 5.0 & 5.9 & 8.2 & 10.4 & 12.6 & 14.4 & 23.4 & 23.4 \\
\hline Africa/Middle & 8 & 8.0 & 8.3 & 9.8 & 12.4 & 20.2 & 13.0 & 15.0 & 32.3 \\
East & & & & & & & & & \\
\hline Asia Pacific & 53 & 2.7 & 3.4 & 3.3 & 3.9 & 4.2 & 6.0 & 10.4 & 10.7 \\
Japan & 28 & 3.4 & 2.6 & 2.6 & 4.3 & 0.8 & 1.2 & 6.7 & 10.3 \\
\hline Europe & 93 & 8.6 & 9.9 & 14.9 & 16.8 & 26.9 & 28.1 & 28.9 & 38.1 \\
France & 15 & 11.8 & 15.7 & 30.3 & 30.0 & 36.8 & 34.8 & 44.6 & 45.1 \\
Germany & 16 & 10.3 & 12.7 & 13.6 & 15.2 & 32.4 & 36.0 & 42.6 & 43.8 \\
UK & 16 & 9.0 & 7.6 & 16.6 & 17.8 & 17.1 & 14.6 & 24.1 & 20.6 \\
\hline Latin America & 9 & 1.4 & 1.9 & 2.1 & 2.3 & 12.2 & 7.6 & 19.3 & 25.2 \\
\hline North America & 87 & 2.9 & 3.5 & 7.0 & 8.2 & 4.2 & 3.6 & 14.3 & 14.1 \\
USA & 79 & 3.0 & 3.7 & 7.6 & 8.9 & 3.6 & 7.1 & 14.3 & 14.6 \\
\hline
\end{tabular}

Note: The data show the position of the largest 250 firms in the specific years so the sample changes slightly by year as firms enter or leave the list.

Source: Deloitte $(2007 ; 2013 ; 2016)$ 


\section{References}

Alexander, N., Quinn, B. (2002) International retail divestment, International Journal of Retail and Distribution Management, 30(2): 112-125.

Amankwah-Amoah, J., Zhang, N., Sarpong, D. (2013) Leaving behind a turbulent past: insights of divestments from China. Strategic Change: briefings in Entrepreneurial Finance, 22: 295-306.

Andersen, K. V. (2013) The problem of embeddedness revisited: Collaboration and market types. Research Policy, 42(1): 139-148.

Aoyama, Y. (2007) Oligopoly and the structural paradox of retail TNCs: an assessment of Carrefour and Wal-Mart in Japan, Journal of Economic Geography, 7(4): 471-490.

Bartlett, C. A., Ghoshal, S. (1989) Managing across borders: The transnational solution. Boston: Harvard Business School Press,

Bartlett, C. A., Ghoshal, S. (1990) The multinational corporation as an interorganizational network, The Academy of Management Review, 15(4): 603-625

Beckert, J. (2007) The great transformation of embeddedness: Karl Polanyi and the new economic sociology. Max-Plank-Institut für Gesellschaftsforschung Discussion Paper $07 / 1$

Betancourt, R. (2004) The Economics of Retailing and Distribution. Cheltenham: Edward Elgar.

Bianchi, C. C., Arnold, S. J. (2004) An institutional perspective on retail internationalization success: Home Depot in Chile. International Review of Retail, Distribution and Consumer Research, 14(2): 149-169.

Block, F. Somers, M. R. (2014) The Power of Market Fundamentalism: Karl Polanyi's Critique. Cambridge, MA: Harvard University Press

Bonache, J., Cervino, J. (1997) Global integration without expatriates, Human Resource Management Journal, 7(3): 89-100.

Brailly, J., Favre, G., Chatellet, J., Lazega, E. (2016) Embeddedness as a multilevel problem: A case study in economic sociology. Social Networks, 44: 313-333.

Buckland-Wright, A. (2016) Transnational Retail in Southeast Asia: Transformation and Regulation in the National Retail Markets of Malaysia and Thailand. PhD thesis, University of Manchester.

Burt. S. (2014) The Metro Group: internationalizing the cash and carry format. In J. Dawson, M. Mukoyama (eds) Global Strategies in Retailing, pp. 201-226. Abingdon: Routledge.

Burt, S., Dawson, J., Sparks, L. (2003). Failure in international retailing: research propositions, International Review of Retail and Distribution Management, 13(4): 344-373.

Burt, S., Mellahi, K., Jackson, P., Sparks, L. (2002) Retail internationalization and retail Failure: issues from the case of Marks and Spencer. International Review of Retail Distribution and Consumer Research, 12(2): 191-219.

Burt, S., Johansson, U., Dawson. J. (2016) International Retailing as Embedded Business Models, Journal of Economic Geography, 16(3): 715-747. 
Cao, L. (2011) Dynamic capabilities in a turbulent market environment: empirical evidence from international retailers in China. Journal of Strategic Marketing, 19(5): 455-469.

Chan, A. (2011) Editor. Walmart in China. Ithaca: ILR

Chinomona, R., Sibanda, D. (2012) When global expansion meets local realities in retailing: Carrefour's glocal strategies in Taiwan. International Journal of Business and Management, 8(1): 44-59.

Christopherson, S. (2007) Barriers to 'US Style' lean retailing: the case of Wal-Mart's failure in Germany, Journal of Economic Geography, 7(4): 451-469.

Chuang, M-L., Donegan, J. J., Ganon, M. W., Wei, K. (2011) Walmart and Carrefour experiences in China: resolving the structural paradox, Cross Cultural Management, 18(4): 443-463.

Coe, N.M, Dicken, P., Hess, M. (2008) Global production networks: realizing the potential, Journal of Economic Geography, 8(3): 279-295.

Coe, N.M., Hess, M. (2005) The internationalisation of retailing: implications for supply network restructuring in East Asia and Eastern Europe, Journal of Economic Geography, 5(4): 449-473.

Coe, N. M., Lee, Y-S. (2006) The strategic localization of transnational retailers: the case of Samsung-Tesco in South Korea. Economic Geography, 82(1): 61-88.

Coe, N. M., Lee, Y-S. (2013) 'We've learnt how to be local': the deepening territorial embeddedness of Samsung-Tesco in South Korea. Journal of Economic Geography, 13(2): 327-356.

Coyle, W. (2006) A revolution in food retailing underway in the Asia-Pacific region. USDA AmberWaves, 3(4): 22-29.

Dawson, J. (2003) Towards a model of the impacts of retail internationalisation. In J. Dawson, M. Mukoyama, C.C. Sang, R.Larke (eds), The Internationalisation of Retailing in Asia, pp..189-209. London: Routledge Curzon.

Dawson J. (2013) Retailer activity in shaping food choice. Food Quality and Preference, 28(1): 339-347.

Dawson, J., Mukoyama, M. (2014) Building international strategy with formats and formulae. In J. Dawson, M. Mukoyama (eds). Global Strategies in Retailing: Asian and European Experiences, pp. 37-54. London: Routledge.

De Jong, A., DeJong, D.V., Mertens, G., Roosenboom, P. (2007) Investor relations, reputational bonding, and corporate governance: the case of Royal Ahold, Journal of Accounting and Public Policy, 26(3): 328-375.

Deloitte (2007) Global Powers of Retailing, Deloitte Touche Tohmatsu Ltd

Deloitte (2013) Global Powers of Retailing, Deloitte Touche Tohmatsu Ltd

Deloitte (2016) Global Powers of Retailing, Deloitte Touche Tohmatsu Ltd

Dupuis, M., Fournioux, J. (2006) Building an international retail strategy. In J. Dawson, R. Larke, M. Mukoyama (eds) Strategic Issues in International Retailing, pp. 51-70. Abingdon: Routledge. 
Elg, U., Deligonul, S.Z., Ghauri, P. N., Danis, W., Tarnovskaya, V. (2012) Market driving strategy implementation through global supplier relationships. Industrial Marketing Management, 41(6): 919-928.

Endo, G. (2014) The key role of intermediaries in Thailand's fresh food distribution system, International Review of Retail Distribution and Consumer Research, 24(5): 544-563.

Faulconbridge, J. R., Muzio, D. (2015) Transnational corporations shaping institutional change: The case of English law firms in Germany. Journal of Economic Geography, 15(6): 1195-1226.

Ferdows, K., Lewis, M.A., Machuca, J.A.D. (2004) Rapid fire fulfilment. Harvard Business Review, 8(11): 104-110.

Fernie, J. (1995) International comparisons of supply chain management in grocery retailing. Service Industries Journal, 15(4): 134-147.

Ferraris, A. (2014) Rethinking the literature on "multiple embeddedness" and subsidiary-specific advantages. Multinational Business Review, 22(1): 15-33.

Frasquet, M., Molla, A., Dawson, J. (2013) Post-entry internationalisation activity of retailers: an assessment of dynamic capabilities. Management Decision 51(7): 1510-1527.

Gamble, J. (2006) Introducing western-style HRM practices to China: shopfloor perceptions in a British multi-national, Journal of World Business, 41(4): 328-343.

Gamble, J. (2010) Transferring organizational practices and the dynamics of hybridization: Japanese retail multinationals in China, Journal of Management Studies, 47(4): 705 732.

Gamble J (2011) Multinational Retailers and Consumers in China. Basingstoke: Palgrave Macmillan

Gandolfi, F., Strach, P (2009) Retail internationalization: gaining insights from the Wal-Mart experience in South Korea, Review of International Comparative Management, 10(1): 187-199.

Geels, F. W. (2014) Reconceptualising the co-evolution of firms-in-industries and their environments: Developing an inter-disciplinary Triple Embeddedness Framework. Research Policy, 43(2): 261-277.

Gibbon P (2001) At the cutting edge? UK clothing retailers' global sourcing patterns and practices and their implications for developing countries, Centre for Development Research, University of Copenhagen

Goldman, E., (2001) The transfer of retail formats into developing economies, the example of China, Journal of Retailing, 77(2): 221-242.

Grabher, G. (1993) (ed). The Embedded Firm. London: Routledge

Granovetter, M. (1985) Economic action and economic structure: the problem of embeddedness. American Journal of Sociology, 91(3): 481-510.

Granovetter, M. (1992) Economic institutions as social constructions: A framework for analysis. Acta Sociologica, 35(1): 3-11.

Granovetter, M. (2005) The impact of social structure on economic outcomes. Journal of Economic Perspectives, 19(1): 33-50. 
Heidenreich, M. (2012a) (ed) Innovation and Institutional Embeddedness of Multinational Companies. Cheltenham: Edward Elgar.

Heidenreich, M. (2012b) The social embeddedness of multinational companies: a literature review. Socio-Economic Review, 10: 549-579.

Hellier, R. (2001) Inside Zara, Forbes.com, 05/25/2001

Herring, L., Hui, D., Morgan, P., Tufft, C. (2012) Inside China's hypermarkets: Past and prospects. McKinsey \& Co, Consumer and Shopper Insights, May.

Hess, M. (2004) 'Spatial' relationships? Towards a reconceptualization of embeddedness. Progress in Human Geography, 28(2): 165-186.

Hoenen, A. K., Nell, P. C., Ambos, B. (2014) MNE Entrepreneurial capabilities at intermediate levels: The roles of external embeddedness and heterogeneous environments. Long Range Planning, 47 (1-2): 76-86.

Hollingsworth, J. R., Boyer, R. (1997) Cordination of economic actors and social systems of production. In J. R., Hollingsworth, R., Boyer (eds) Contemporary Capitalism: the embeddednes of institution, pp.1-47. Cambridge: Cambridge University Press.

Huang, L., Liu, A. (2011) China grocery retailers. Hong Kong: Macquarie Research.

Hurt, M., Hurt, S. (2005) Transfer of managerial practices by French food retailers to operations in Poland, Academy of Management Executive, 19(2): 36-49.

Jackson, P. (2004) Local consumption cultures in a globalizing world. Transactions of the Institute of British Geographers, 29:165-178.

Jiang, B., Prater, E. (2002) Distribution and logistics development in China: The revolution has begun. International Journal of Physical Distribution \& Logistics Management, 32(9): $783-798$

Jones, A. (2008) Beyind embeddedness: economic practices and the invisible dimensions of transnational business activity. Progress in Human Geography, 32(1): 71-88.

Jonsson, A., Elg, U. (2006) Knowledge and knowledge sharing in retail internationalisation: IKEA's entry into Russia, International Review of Retail, Distribution and Consumer Research, 16(2): 239-256.

Kim, R.B. (2008) Wal-Mart Korea: challenges of entering a foreign market, Journal of AsiaPacific Business, 9(4): 344-357.

Kotelnikova, Z. (2013) Structural embeddedness and contractual relationships of chain stores and their suppliers in Russian emerging markets. Moscow Higher School of Economics Research Paper, WP BRP 22/SOC/2013

Kumar, N., (1997) The revolution in retailing from market driven to market driving, Long Range Planning, 60(6): 830-835.

Lampel, J. and Bhalla, A. (2008) Embracing realism and recognizing choice in IT offshoring initiatives. Business Horizons, 51(5): 429-440.

Laud, G., Karpen, I. O., Mulye, R., Rahman, K. (2015) The role of embeddedness in resource integration: Complementing S_D logic research through a social capital perspective. Marketing theory, 15(4): 509-543.

Lopez, C. and Fan, Y. (2009) Internationalisation of the Spanish fashion brand Zara, Journal of Fashion Marketing and Management, 13(2): 279-296. 
Lowe, M., Wrigley, N. (2010) The "continuously morphing" retail TNC during market entry: interpreting Tesco's expansion into the United States. Economic Geography, 86(4): 381-408.

Lowe, M., George, G. Alexy, O. (2012) Organizational identity and capability development in internationalizatio: transference, splicing and enhanced imitation in tesco's market entry. Journal of Economic Geography, 12(5)2:1021-1054.

Matusitz, J., Forrester, M. (2009) Successful glocalization practices: the case of Seiyu Japan. Journal of Transnational Management, 14(2): 155-176.

Matusitz, J., Leanza, K. (2009) Wal-Mart: an analysis of the glocalization of the cathedral of consumption in China. Globalizations, 6(2): 187-205.

Matusitz, J., Reyers, A. (2010) A behemoth in India Walmart and glocalisation. South Asia Research, 30(3): 233-252.

Minahan, S. M., Huddleston, P., Bianchi, C. (2012) Costco and the Aussie shopper: a case study of the market entry of an international retailer. International Review of Retail, Distribution and Consumer Research, 22(5): 507-527.

Moore, C. M., Birtwistle, G. (2004) The Burberry business model: creating an international luxury fashion brand. International Journal of Retail \& Distribution Management, 32(8): 412-422.

Oinas, P. (1998) The Embedded Firm. Prelude for a revised geography of enterprise. Doctoral thesis A-143 Helsinki School of Economics and Business Administration

Owens, M., Palmer, M., Zueva-Owens, A. (2013) Institutional forces in adoption of international joint ventures: empirical evidence from British retail multinationals, International Business Review, 22(5): 883-893.

Paché, G. (1995) Speculative inventories in the food retailing industry: a comment on French practices, International Journal of Retail and Distribution Management, 23(12): 36-42.

Palmer, M. (2004) International retail restructuring and divestment: the experience of Tesco, Journal of Marketing Management, 20(9-10): 1075-1105.

Palmer, M., Quinn, B. (2005) An exploratory framework for analysing international retail learning, International Review of Retail, Distribution and Consumer Research, 15(1): 27-52.

Palmer, M., Owens M., de Kervenoal, R. (2010) Paths of least resistance: understanding how motives form in international retail/joint ventures, Service Industries Journal, 30(6): 965989.

Peterson, B., Welch, L.S. (2000) International retailing operations: downstream entry and expansion via franchising, International Business Review, 9: 479-496.

Peck, J. (2013) Disembedding Polanyi: Exploring Polanyian economic geographies. Environemnt and Planning A, 45:1536-1544

Picot-Coupey, K. (2006) Determinants of international retail operation mode choice: towards a conceptual framework based on evidence from French specialised retail chains: International Review of Retail Distribution and Consumer Research, 16(2): 215-237

Polanyi, K. (1944) The Great Transformation, Boston: Beacon Press

Quinn, B., Doherty, A.M. (2000) Power and control in international retail franchising: evidence from theory and practice, International Marketing Review, 17(4/5): 354-372 
Reardon, T., Henson, S., Berdegué,J. (2007) Proactive fast-tracking' diffusion of supermarkets in developing countries: implications for market institutions and trade Journal of Economic Geography,7(4): 399-431

Reardon, T., Timmer, C. P., Minten B. (2012) Supermarket revolution in Asia and emerging development strategies to include small farmers, Proceeding of National Academy of Sciences, July 31 2012, 109(31): 12332-12337

Reddy B. (2013) Media Markt's exit from China. IBS Center for Management Research: Hyderabad.

Rogers, H., Ghauri, P.N., George, K.L. (2005) The impact of market orientation on the internationalisation of retailing firms: Tesco in Eastern Europe, International Review of Retail Distribution and Consumer Research, 15(1): 53-74.

Runfola, A., Guercini, S. (2013) Fast fashion companies coping with internationalization: driving the change or changing the model?, Journal of Fashion Marketing and Management, 17(2): 190-205.

Rungfapaisarn, K. (2012) Cashing in on hydroponic vegetables. The Nation, 5 March 2012.

Sacks, M. A., Uzzi, B. (2000) Networks, transaction costs, and the persistence of interfirm ties: The New York apparel industry, 1985 to 1995. In R., Tzend, B., Uzzi, B. (editors) Embeddedness and Corporate Change in a Global Economy, pp. 79-103. New York: Peter Lang,

Shackleton, R. (1998) Exploring corporate culture and strategy: Sainsbury at home and abroad during the early to mid 1990s, Environment and Planning A, 30: 921-940.

Schröder, C. (2014) The replication of retail fashion formats into foreign countries Wiesbaden: Springer-Gabler

Shi J., Au-Yeung, A. Y. S (2015) An innovation perspective on Chinese retailers' competitive advantage, International Review of Retail, Distribution and Consumer Research, 25(2): 120-144.

Siebers, L. Q (2011) Retail Internationalization in China. Basingstoke: Palgrave Macmillan

Siebers, L.Q. (2016) Hybridization practices as organizational responses to institutional demands: the development of Western retail TNCs in China, Journal of Economic Geography, DOI 10.1093/jeg/lbv041

Sirait G M (2014) Employment Relations in Indonesia's Retail Sector: Institutions, Power Relations and Outcomes. PhD thesis, University of Sydney.

Swoboda, B., Elsner, S. (2013) Transferring the retail format successfully into foreign countries. Journal of International Marketing, 21(1): 81-109

Swoboda, B., Elsner, S., Olejnik, E. (2015) How do past mode choices influence subsequent entry? a study on the boundary conditions of preferred entry modes of retail firms, International Business Review, 24: 506-517

Tacconelli, W., Wrigley, N. (2009) Organizational challenges and strategic responses of retail TNCs in post-WTO-entry China. Economic Geography, 85(1): 49-73.

Tarnovskaya, V., Elg, U., Burt, S. (2008) The role of corporate branding in a market driving strategy, International Journal of Retail and Distribution Management, 36(11): 941961. 
Taylor, M. (2000) Enterprise, power and embeddedness. In E., Vatne, M., Taylor (eds) The Networked Firm in a Glocal World, pp. 199-233, Aldershot: Ashgate

Taylor, M. (2005) Embedded local growth: a theory taken too far. In R.A., Boschma, C., Kloosterman (eds) Learning from Clusters: a critical assessment from an economicgeographical perspective, pp. 68-86. Dordrecht: Springer.

Tokatli, N., (2008) Global sourcing: insights from the global clothing industry - the case of Zara, a fast fashion retailer, Journal of Economic Geography, 8(1): 21-38.

Tokatli, N. (2012) Old firms, new tricks and the quest for profits: Burberry's journey from success to failure and back to success again. Journal of Economic Geography, 12(1): $55-77$.

Tzeng, R., Uzzi, B. (2000) (eds). Embeddedness and Corporate Change in a Global Economy. New York: Peter Lang

Wang, S. (2014) China's New Retail Economy: a geographic perspective. Abingdon: Routledge.

Wang, W., Jaeger, F., Li, X., Wang, X., Zhang, J. (2013). China's food production and cold chain logistics. Paper presented at 5th Int. Workshop on Cold Chain Management at University of Bonn, Germany June 10-11, 2013.

Waldmeir, P. (2009) M\&S admits Shanghai errors. Financial Times, February 9, 2009. Available at: http://www.ft.com/cms/s/0/2bac61ae-f6e2-11dd-8a1f0000779fd2ac.html\#axzz2JC6eGmeZ (accessed 2013-01-28).

Wigley, S., Moore, C. M. (2007) The operationalisation of international fashion retailer success. Journal of Fashion Marketing and Management, 11(2): 281-296.

Wood, S., Coe, N. M., Wrigley, N. (2014) Multi-Scalar localization and capability transference: Exploring embeddedness in the Asian retail expansion of Tesco, Regional Studies, 50(3): 475-495.

Wood, S., Reynolds, J. (2012) Managing communities and managing knowledge: strategic decision making and store network investment within retail multinationals. Journal of Economic Geography, 12(2): 539-565

Wood, S., Reynolds, J. (2013) Knowledge management, organisational learning and memory in UK retail network planning. Service Industries Journal, 33(2): 150-170

Wood, S., Reynolds, J. (2014) Establishing territorial embeddedness within retail TNC expansion: the contribution of store development departments. Regional Studies. 48(8):1371-1390.

Wood, S., Wrigley, N., Coe, N. M. (2016) Capital discipline and financial market relations in retail globalization: insights from Tesco plc, Journal of Economic Geography, DOI: $10.1093 / \mathrm{jeg} / \mathrm{lbv045}$

Wrigley, N., Coe, N. M., Currah, A. (2005) Globalizing retail: conceptualizing the distributionbased TNC. Progress in Human Geography, 29(4): 437-457.

Wu, Z., Pullman, M. E. (2015) Cultural embeddedness in supply networks. Journal of Operations Management, 37: 45-58.

Yeung, H. W-C. (2006) The firm as social networks: An organisational perspective. Growth and Change, 36(3): 309-328. 
Zentes, J., Morschett, D., Scramm-Klein, H (2011) Strategic Retail Management. Wiesbaden: Gabler.

Zukin, S., DiMaggio, P. (1990) (eds). Structures of Capital: The social organization of the economy. Cambridge: Cambridge University Press. 